Acta vet. scand. $1972,13,191-196$.

From the Department of Medicine I, Royal Veterinary College, Stockholm, Sweden.

\title{
MAMMARY SECRETION OF IgG IN SOWS
}

\author{
By \\ Kjell Martinsson
}

\begin{abstract}
MARTINSSON, KJELL: Mammary secretion of IgG in sows. Acta vet. scand. 1972, 13, 191-196. - The IgG-concentration was determined in serum of 3 pregnant sows before and after partus and in colostrum of 7 sows $0-6$ days post partum. The IgG-concentration decreased in serum before partus and increased after partus. The lowest value $(1.5 \mathrm{~g} / 100 \mathrm{ml})$ was observed at partus. The results indicate that IgG is transmitted from serum to colostrum.

The concentration of $\mathrm{IgG}$ in colostrum was found to be $2.1-10.4$ $\mathrm{g} / 100 \mathrm{ml}$ at partus. The concentration decreased very fast during the first day post partum. During 3-6 days post partum the IgG concentration was rather constant $(0.3-0.5 \mathrm{~g} / 100 \mathrm{ml})$. The importance of the results for the passive immunization of piglets is discussed.
\end{abstract}

immunoglobulins; swine; mammary secretion.

The importance of colostral immunoglobulins of mammals for the transfer of immunity from the mother to her descendants has been claimed by many authors (Booman et al. 1958, Greenbaum \& Miller 1960, Dixon et al. 1961, Pierce \& Feinstein 1965). There are also much evidence that the colostral immunoglobulins are transmittent from serum to colostrum and not synthesized in the mammary glands (Askonas et al. 1954, Dixon et al., Feldman 1961).

The colostrum represents the only source of antibody transfer from mother to offspring in the foal, lamb, calf and pig. In newborn piglets very small levels of immunoglobulin (IgG) can be detected with sensitive techniques (Sterzl et al. 1960, Martinsson 1970). Studies by Binns (1967) indicate that the low levels of 
immunoglobulins observed in pre-suckled piglets are produced by the foetus.

In colostrum of sows there is a dramatic fall during the first $24 \mathrm{hrs}$. post partum of both the total protein and the immunoglobulins (Morgan \& Lecce 1964, Schone 1965, Bourne 1969).

In cows decreased levels of serum gammaglobulins are observed ante partum depending on the secretion into colostrum (Dixon et al., Pierce 1961). Post partum the levels were found to increase probably depending on cessation of the gammaglobulin transfer to colostrum.

The object of this investigation was to study the serum IgG levels ante- and post partum and the changes in the IgG content of colostrum in the immediate post-partum period.

\section{MATERIAL AND METHODS}

Animals. Seven sows, 1.5-3 years old of Swedish landrace were used. Blood samples were taken regularly ante- and post partum for IgG determinations from 3 sows. Pooled samples of colostrum were taken daily from the functional teats after delivery. The first samples were taken before the piglets had suckled. Colostrum samples were easily obtained during the first day post partum, but later on they were collected after injection of 5 i.u. of oxytocin. Blood serum was stored at $-20^{\circ} \mathrm{C}$. Colostrum samples were defatted by centrifugation $(3000 \times \mathrm{g}$ for $10 \mathrm{~min}$.) and stored at $-20^{\circ} \mathrm{C}$.

IgG-determinations. Serum and colostral IgG were determined by the single radial diffusion test (Mancini et al. 1965). Monospecific anti-IgG was prepared as described by Martinsson (1970).

\section{RESULTS}

In 2 of 3 sows examined the serum IgG levels were found to decrease from about $2.5 \mathrm{~g} / 100 \mathrm{ml} 14$ days before partus to a minimum level of about $1.5 \mathrm{~g} / 100 \mathrm{ml}$ at partus. Post partum the IgG levels increased during the first few days in all 3 sows to about $2.0 \mathrm{~g} / 100 \mathrm{ml}$ (Fig. 1).

In Fig. 2 the IgG levels of colostrum from 7 sows are given. The levels at partus ranged from 2.1 to $10.4 \mathrm{~g} / 100 \mathrm{ml}$. A dramatic fall was observed during the first day post partum, and between the 3rd and 6th day after partus the IgG-content was rather constant at a level of about $0.3-0.5 \mathrm{~g} / 100 \mathrm{ml}$. 


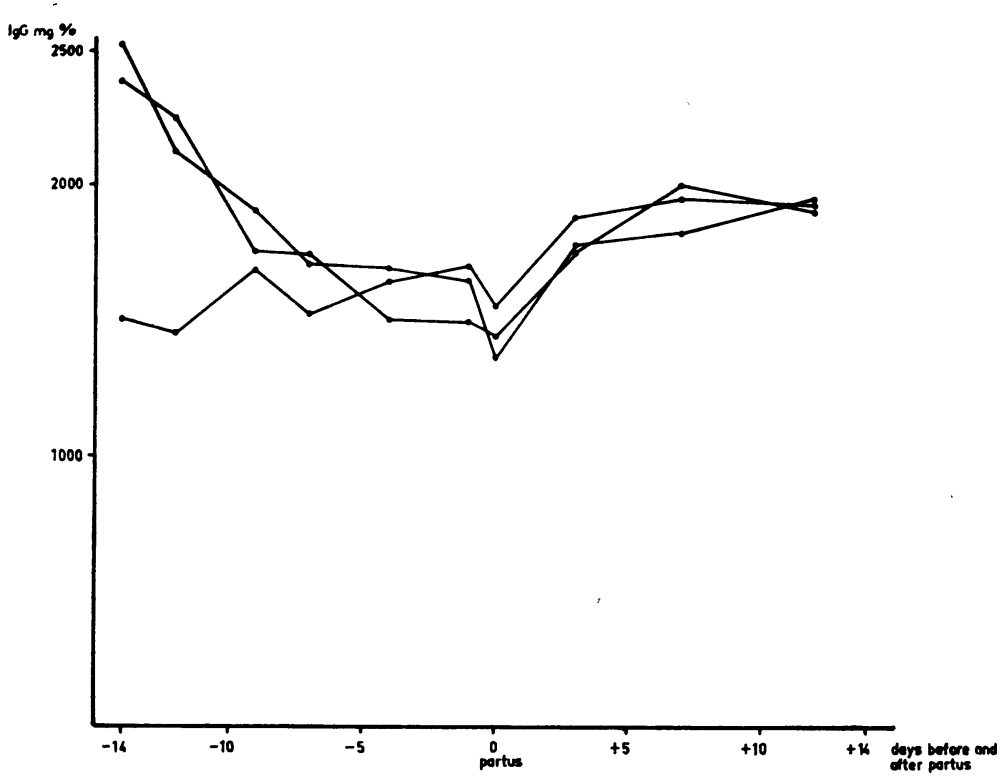

Figure 1. The serum concentration of IgG in 3 sows before and after partus.

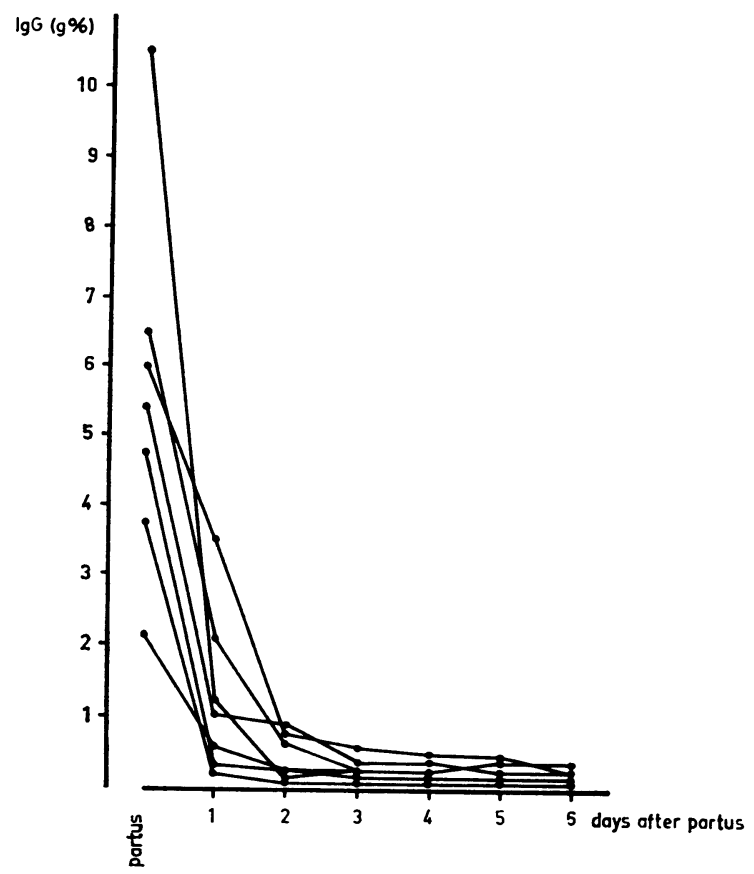

Figure 2. The IgG concentration of colostrum in 7 sows after partus. 


\section{DISCUSSION}

In these investigations the minimum levels of IgG in serum of sows were observed at partus as were also shown in cows by Pierce (1961) and Dixon et al. (1961). The changes of the IgG levels before partus may be due to a transmission of IgG to colostrum which domineers over the active production in serum. This theory is further supported by the finding that labelled immunoglobulins pass unchanged from maternal serum to colostrum (Larsson \& Gillespie 1957). After delivery this transmission ceases and consequently the serum IgG levels will increase.

The results obtained support the theories that serum IgG is transferred to colostrum also in sows judging from the decreasing levels in serum ante partum. Of the 3 sows examined only 2 showed this pattern. In the third sow the decrease is not pronounced during the ante-partum period of 2 weeks. This may be due to a previous outset of transmission to colostrum or an increased synthesis of IgG interfering with the transmission to colostrum.

The low serum IgG levels observed at partus are probably not of significance for the infections which often appear at this time in sows. Thus in man IgG levels of about $0.2 \mathrm{~g} / 100 \mathrm{ml}$ were sufficient for the protection against infections in cases of agammaglobulinaemia (cit. Janeway et al. 1967). Furthermore, colostrumdeprived piglets raised in a non-sterile environment could be protected by supplementation of immunoglobulin giving serum IgG levels of about $0.35 \mathrm{~g} / 100 \mathrm{ml}$ (Martinsson 1970).

The IgG content of colostrum varied very much at partus (range $2.1-10.4 \mathrm{~g} / 100 \mathrm{ml}$ ). It may indicate that piglets from sows with a low IgG level of colostrum at partus are likely to have immunological disadvantages over piglets born of sows with a high IgG level. This may, in part, account for the hypogammaglobulinaemia found by Breitling (1965) in $17 \%$ of litters examined. In such litters almost all piglets had a hypogammaglobulinaemia and the piglets were also found to have an incidence of infections twice that of normal ones.

In 7 sows examined no age differences of the colostral IgG levels at partus were apparent, as was also found by Bourne (1969). The dramatic fall post partum in the concentration of IgG also seemed to be unrelated to the initial level (Fig. 2).

One-2 days post partum the IgG levels in colostrum were rather constant at a level of about $0.3-0.5 \mathrm{~g} / 100 \mathrm{ml}$. This in- 
dicates that ingestion of colostrum immediately after birth is of greatest importance to receive an adequate passive immunity. It should also be borne in mind that the ability of the piglets to absorb antibodies greatly decreases during the first day of life.

From this study it may also be concluded that piglets born early in the farrowing process are likely to have immunological advantages over their littermates born later. Furthermore piglets born late have greater competition for teats which may also influence on the supply of colostrum and thus on the passive immunity.

\section{REFERENGES}

Askonas, B. A., P. N. Campbell, J. H. Humphrey \& T. G. Work: The source of antibody globulin in rabbit milk and goat colostrum. Biochem. J. 1954, 56, 597-601.

Binns, R. M.: Institute of animal physiology. Report for 1966-1967. Babraham, Cambridge 1967.

Booman, K. E., B. E. Dodd \& M. Gunther: A consideration of colostrum and milk as sources of antibodies which may be transferred to the newborn baby. Arch. Dis. Childh. 1958, 33, 24-29.

Bourne, F. J.: Studies on colostral and whey proteins in the sow. Animal Prod. 1969, 11, 337-343.

Breitling, E.: Untersuchungen zur hypo- bzw agammaglobulinämi der Ferkel. (Investigations on the hypo- and agammaglobulinemia in piglets). Thesis. München 1965.

Dixon, F. J., F. O. Weigle \& J. J. Vazquez: Metabolism and mammary secretion of serum proteins in the cow. J. Lab. Invest. 1961, 10, 261-237.

Feldman, J. D.: Fine structure of the cow's udder during gestation and lactation. J. Lab. Invest. 1961, 10, 238-255.

Greenbaum, B. S. \& L. Miller: Antibody in milk and its role in passive immunization. J. Lab. clin. Med. 1960, 55, 220-244.

Janeway, C. A., F. S. Rosen, E. Merler \& C. A. Alper: The Gammaglobulins. Little Brown \& Company, Boston 1967.

Larsson, B. L. \& D. C. Gillespie: Origin of the major specific proteins in milk. J. biol. Chem. 1957, 227, 565-573.

Mancini, G., A. O. Corbonara \& J. F. Heremans: Immunochemical quantitation of antigens by single radial immunodiffusion. Immunochemistry 1965, 2, 235.

Martinsson, $K$. : Immunoglobulin therapy in piglets. Acta vet. scand. 1970, 11, suppl. 29.

Morgan, D. O. \& J. G. Lecce: Electrophoretic and immunoelectrophoretic analysis of proteins in the sow's mammary secretion throughout lactation. Res. Vet. Sci. 1964, 5, 332-339.

Pierce, A. E.: Proteinuria in the newly born. Proc. roy. Soc. Med. 1961, $54,996-999$. 
Pierce, A. E. \& A. Feinstein: Biophysical and immunological studies on bovine immunoglobulins with evidence for selective transport within the mammary gland from maternal plasma to colostrum. Immunology 1965, 8, 106-123.

Schone, R.: The serum protein picture of sow colostrum. Thesis, Hannover 1965.

Sterzl, J., J. Kostka, L. Riha \& L. Mandel: Attempts to determine the formation and character of gammaglobulin and of natural and immune antibodies in young pigs reared without colostrum. Folia microbiol. (Praha) 1960, 5, 29—45.

\section{SAMMANFATTNING}

Sekretionen av IgG till kolostrum hos suggor.

IgG-halten har bestämts i serum hos 3 dräktiga suggor före och efter partus samt $i$ kolostrum $0-6$ dagar efter partus hos 7 suggor. IgG-halten visades sjunka i serum före partus, för att efter partus åter öka. Vid partus var IgG-halten lägst $(1,5 \mathrm{~g} / 100 \mathrm{ml})$. Resultaten antyder att IgG transmitteras från serum till kolostrum före partus. Halten IgG i kolostrum varierade vid partus mellan 2 och $10,4 \mathrm{~g} / 100 \mathrm{ml}$. Halten sjönk mycket snabbt under första dygnet efter partus. Under 3-6 dygnet efter partus var IgG-halten relativt konstant $(0,3-0,5 \mathrm{~g} / 100 \mathrm{ml})$. Resultatens betydelse för den passiva immuniseringen av spädgrisar diskuteras.

(Received April 2, 1971).

Reprints may be requested from: Kjell Martinsson, Dept. of Medicine I, Royal Veterinary College, S-104 05 Stockholm 50, Sweden. 